\title{
ERRATUM
}

\section{Field validation of food outlet databases: the Latino food environment in North Carolina, USA - ERRATUM}

\author{
Pasquale E Rummo, Penny Gordon-Larsen and Sandra S Albrecht
}

First published online 21 July 2014

doi: 10.1017/S1368980014001281, published online by Cambridge University Press 17 June 2014

The authorship order is incorrect, instead of:

Pasquale E Rummo, Penny Gordon-Larsen and Sandra S Albrecht

It should read:

Pasquale E Rummo, Sandra S Albrecht and Penny Gordon-Larsen

\section{Reference}

Rummo PE, Gordon-Larsen P \& Albrecht SS. Field validation of food outlet databases: the Latino food environment in North Carolina. Public Health Nutrition, published online by Cambridge University Press 17 June 2014, doi 10.1017/S1368980014001281. 